\title{
Farm-to-school grant funding increases children's access to local fruits and vegetables in Oregon
}

\author{
Kristen C. Giombi a* \\ RTI International \\ Anupama Joshi $b$ \\ National Farm to School Network \\ Caroline Rains ${ }^{\mathrm{c}}$ and Jean Wiecha ${ }^{\mathrm{d}}$ \\ RTI International
}

Submitted December 12, 2018 / Revised February 4, May 14, August 9, October 30, and November 15, 2019 /

Accepted December 3, 2019 / Published online April 14, 2020

Citation: Giombi, K. C., Joshi, A., Rains, C., \& Wiecha, J. (2020). Farm-to-school grant funding increases

children's access to local fruits and vegetables in Oregon. Journal of Agriculture, Food Systems, and Community

Development, 9(3), 139-148. https://doi.org/10.5304/jafscd.2020.093.010

Copyright (C) 2020 by the Authors. Published by the Lyson Center for Civic Agriculture and Food Systems. Open access under CC-BY license.

\begin{abstract}
We undertook this study to measure the reach of Oregon's legislated farm-to-school grant program among school districts and children, particularly low income, and examine changes in local purchasing, particularly fruit and vegetables, and the use of produce from school gardens in school meals. We conducted descriptive analyses to examine the

a* Corresponding author: Kristen C. Giombi, RTI International; 3040 E. Cornwallis Road, P.O. Box 12194; Research Triangle Park, NC 27709 USA; +1-919-541-7330; kgiombi@rti.org

b Anupama Joshi, National Farm to School Network, San Francisco, CA 94129 USA.

Joshi is now Executive Director, Blue Sky Funders Forum, New York, NY USA; anupama@blueskyfundersforum.org

c Caroline Rains, RTI International; 3040 E. Cornwallis Road, P.O. Box 12194; Research Triangle Park, NC 27709 USA; +1-919-485-5607; crains@,rti.org

d Jean Wiecha, RTI International; 3040 E. Cornwallis Road, P.O. Box 12194; Research Triangle Park, NC 27709 USA; +1-781-434-1739; jwiecha@,rti.org
\end{abstract}

reach and paired two-sample t-tests to examine average purchases of local products between school year 2014-2015 (baseline) and 2015-2016 (intervention). The study results indicate that the number of nonwhite students attending a district participating in farm-to-school nearly doubled in the intervention, and $89 \%$ of children eligible for free and reduced-price meals attended schools in participating districts compared with 39\% of eligible children at baseline. Eighty-one percent of participating districts were low income, which is much higher than the percentage of districts characterized as low income statewide (65\%). The policy also increased the average total local food purchases for low-income districts, particularly fruits and vegetables. The results suggest that the opt-in approach to the grant program facilitated greater

\section{Funding Disclosure}

The research reported in this article was funded by Healthy Eating Research (HER) and the Robert Wood Johnson Foundation (RWJF). 
participation from low-income districts that may otherwise have not accessed the grant program. Oregon's policy approach of designating funds for procurement and/or education grants (versus generic farm-to-school grants to be used at the discretion of the district) enabled the prioritization of these activities in grantee districts. Future research can help develop a more thorough understanding of the long-term impacts of Oregon's farm-toschool policy on children's health outcomes and on other intended outcomes on farmers and the local economy.

\section{Keywords}

Farm to School, School Meals, Grant Funding, Fruits and Vegetables, Low Income

\section{Introduction and Literature Review}

Farm-to-school implementation differs by site but includes at least one of three core elements:

(1) procurement of local foods for cafeteria meals, snacks, or taste tests; (2) educational activities related to agriculture, food, and nutrition; and (3) hands-on learning activities through school gardens (National Farm to School Network [NFSN], n.d.). Several studies indicate that farm-to-school activities provide an opportunity for students to experience local food in school meals and increase their knowledge of, preference for, and consumption of fruits and vegetables through involvement in educational activities (Bontrager Yoder et al., 2014; Joshi, Azuma, \& Feenstra, 2008; Koch, Wolf, Graziose, Gray, Trent, \& Uno, 2017; Kropp et al., 2018; Morris \& Zidenberg-Cherr, 2002; Murphy, 2003; Schmidt, Kolodinsky, \& Symans, 2006; Ratcliffe, Merrigan, Rogers, \& Goldberg, 2009; Savoie-Roskos, Wengreen, \& Durward, 2017). Children in the United States underconsume fruits and vegetables (National Cancer Institute [NCI], 2018). However, since children consume as much as half of their daily calories at school (Cullen \& Chen, 2017), making farm-to-school one of several potential strategies for improving comprehensive nutrition programs could increase fruit and vegetable consumption in preschool through high school (Hayes, Contento, \& Weekly, 2018).

Farm-to-school programs are more likely to be operational in states with farm-to-school policies that support local procurement, school gardens, and/or experiential education activities (Schneider, Chriqui, Nicholson, Turner, Gourdet, \& Chaloupka, 2012). Forty-six states, the District of Columbia, and one territory have farm-to-school legislation in process or in place (NFSN \& Center for Agriculture and Food Systems, 2019). However, support of the three farm-to-school core elements (local procurement, school gardens, and experiential education) varies significantly by policy. The overall policy strategies (grants, incentives to purchase local product, proclamations, and/or staffing at state agencies) also differ.

These differences pose a challenge for generalizing the impact of policies on program implementation across states. Using data from 2006 through 2009, Nicholson, Turner, Schneider, Chriqui, and Chaloupka (2014) found that schools in states with farm-to-school-supported laws served higher amounts of fruits and vegetables in school meals.

In 2007, Oregon was one of the first states to pursue legislation to formalize a grant program for the procurement of local foods and educational activities related to farm-to-school. While the 2007 bill did not pass, legislation supporting a farm-toschool pilot program passed into law in 2011. In 2015, Oregon's legislature passed a more comprehensive bill, which had a unique opt-in feature for procurement. Through this bill, schools automatically received funds to implement farm-to-school procurement, compared to prior state policy that only offered grant funding to Oregon schools through a competitive program.

Previous studies have indicated that school districts with lower per capita income have the lowest probability of serving local food (Ralston, Beaulieu, Hyman, Benson, Smith 2017). McCarthy, Steiner, and Houser (2017) similarly found that as the percentage of students eligible for free and reducedprice lunch at a school increased, the odds of having a farm-to-school program decreased. The optin feature of the Oregon policy in question is relevant because all districts (irrespective of free or reduced-price meal eligibility) could opt-in to receive grant funds. These funds could be used for local procurement without a formal application process, hence reducing the barriers to participation, particularly among low-income districts 
This study on Oregon's first of its kind farmto-school policy can provide guidance on best practices for revising current state policy or creating new farm-to-school programs. This paper aims to evaluate the opt-in procurement feature of Oregon's farm-to-school grant program during the 2015-2016 time frame. Specifically, this paper will: (1) examine reach into Oregon's school districts and children, particularly low-income children; (2) examine expenditures on local purchasing, particularly fruits and vegetables, and the use of school garden produce in school meals among procurement districts; and (3) compare the impacts of the opt-in and competitive policy strategies.

\section{Methods}

\section{Intervention}

Since 2011, the Oregon legislature has passed several bills that we define as the three "eras" of Oregon farm-to-school: a pilot program, a competitive program, and an opt-in program:

- 2011: A pilot program was administered to assess whether competitively awarded grant funding facilitated the purchase of Oregongrown and -processed foods, particularly in low-income districts. The grant program also implemented farm- and garden-based educational programs in over half of the districts that applied (US $\$ 200,000$ disbursed to 11 school districts out of 20 applicants) (House Bill 2649, 2013).

- 2013: A competitive grant program was administered with similar procurement and education components as the pilot program with a funding increase of US $\$ 1$ million (total of US $\$ 1.2$ million disbursed to 22 school districts out of 33 applicants in the 20132015 biennium).

- 2015: The grant program received a onetime infusion of US $\$ 3.3$ million and separated funds for procurement $(80 \%)$ and education (20\%) grants (total US $\$ 4.5$ million in grants for 2015-2017 biennium).

- Procurement grants included an opt-in feature with funding allocation prorated for average student participation in the National School Lunch Program (NSLP) (124 districts out of a total of 212 opted in for 2015-2016; 144 districts opted in for 2016-2017).

- Education grants continued to have a competitive application (Upstream Public Health \& Oregon Farm to School and School Garden Network, 2018) with priority for organizations serving a high percentage of free and reduced-price lunch-eligible students in the NSLP (24 grants awarded out of 55 applicants, serving 30 school districts).

- 2017: Grant funding was maintained at US $\$ 4.5$ million for the 2017-2019 biennium with modifications:

- Procurement grants continued to be optin and received $80 \%$ of overall funding, but could not be used to supplant existing purchases of Oregon-grown foods.

- Education grants continued to be competitive, but eligibility criteria expanded.

\section{Data Sources}

This study used two data sets from the Oregon Department of Education (ODE). The first data set was 2014-2016 data from the opt-in procurement grantees. Baseline survey data were collected in September 2015, which was before implementation of the opt-in procurement grant program and reflected local procurement activities from 20142015; intervention survey data were collected in September 2016, a year after the start of the opt-in program. These data provided information on each grantee's farm-to-school activities (e.g., use of materials to promote Oregon foods, incorporation of school garden produce into cafeteria meals, taste tests, total food budget for school meals); local procurement methods (e.g., direct purchase, wholesaler or distributor, growers' cooperative); and types of local foods purchased. This includes the amount of food budget expended on different local product categories (e.g., processed fruits and vegetables, unprocessed fruits and vegetables, grains, dairy, beef). 
The second data set was district-level data on student enrollment, race, and free and reducedprice lunch eligibility, which are collected annually by ODE. This study used these data from 2014 2015 (baseline) and 2015-2016 (intervention) to capture the number and demographics of students reached by the opt-in procurement grant program.

\section{Data Quality}

The quality of some of the ODE baseline and intervention data was problematic because districts were not required to track information on local food purchases before receiving grant funding during baseline. Additionally, districts were learning the reporting process during the intervention year. ODE performed quality checks on the data, particularly for district food expenditures, and flagged inconsistencies and missing or unrealistic numbers between baseline and intervention data. To address the discrepancies, ODE first telephoned district grantees to discuss the reported data. For fruits and vegetables, $58 \%$ of discrepancies were corrected by telephone. If ODE did not receive a response, they used data from the district's reimbursement claims to update the data, which corrected $25 \%$ of the discrepancies for fruits and vegetables-a conservative correction because the district could have purchased more local products than were shown in its reimbursement claims. ODE updated the remaining $17 \%$ of fruit and vegetable discrepancies from reports submitted by distributors who worked with the districts. This correction is also conservative because districts can purchase products directly from farmers.

Additionally, ODE's baseline year and intervention year reports did not collect data on whether the districts received funding to purchase local foods from sources other than the ODE grant program. These reports also did not provide information on whether U.S. Department of Agriculture (USDA) entitlement funds for school meal programs were used to purchase local products.

\section{Data Analyses}

Demographic characteristics of all of Oregon's school districts were descriptively compared with the demographic characteristics of districts that participated in the opt-in program. This compari- son was used to understand the opt-in program's reach, especially into low-income school districts. A paired two-sample $t$-test was used to determine whether the average purchases of local products (all products and specifically local produce) were significantly higher the year of the intervention compared with the baseline. We tested the difference for all opt-in districts, for low-income opt-in districts, and for high-income opt-in districts. A low-income district was defined the same as Title I: $40 \%$ of students enrolled in the district qualify for free and reduced-price lunches (U.S. Department of Education, 2018). Opt-in districts were defined as those districts choosing to receive procurement funds for 2015-2016. Reach measures included the number of students who attended school in an optin district; students participating in federal school meal programs in opt-in districts; opt-in districts' expenditures on local food purchases, particularly fruit and vegetable purchases; and opt-in districts that incorporated school garden produce into cafeteria meals. Special attention was paid to low-income opt-in districts because these districts serve a larger proportion of children participating in the school nutrition programs, and the amount of grant funding districts received depended on NSLP participation.

RTI International's Committee for the Protection of Human Subjects, which operates as RTI International Institutional Review Board, reviewed the study and deemed it exempted from Institutional Review Board approval.

\section{Results}

Oregon public school student enrollment in 20152016 was approximately 576,400 students, with $75 \%$ to $78 \%$ of Oregon's school-aged population attending public schools. The ODE consists of 212 school districts and 1,485 schools. Table 1 provides some characteristics of all Oregon school districts compared with the opt-in districts. For example, of the 124 opt-in school districts, 100 (81\%) were low-income districts, much higher than the percentage of districts characterized as low income $(65 \%)$ statewide. A larger proportion (49\%) of optin districts were medium-size districts with fewer small districts choosing to opt-in. Furthermore, only $10 \%$ of all districts had the opportunity to 
Table 1. Demographic Characteristics of Oregon School Districts $(N=212)$ and Opt-In Grantee Districts ( $N=124)$ for 2015-2016

\begin{tabular}{|c|c|c|}
\hline & Percentage of All School Districts $(n)$ & Percentage of Opt-In Districts $(n)$ \\
\hline \multicolumn{3}{|l|}{ District Size } \\
\hline Small (1-999 students) & $59 \%(125)$ & $38 \%(47)$ \\
\hline Medium (1,000-6,999 students) & $33 \%(70)$ & $49 \%(61)$ \\
\hline Large (more than 7,000 students) & $8 \%(17)$ & $13 \%(16)$ \\
\hline \multicolumn{3}{|l|}{ District Income Status ${ }^{c}$} \\
\hline Low income & $65 \%(138)$ & $81 \%(100)$ \\
\hline High income & $15 \%(32)$ & $19 \%(24)$ \\
\hline Unknowna & $20 \%(42)$ & \\
\hline \multicolumn{3}{|l|}{ \% Nonwhite Students a, b } \\
\hline $0-25 \%$ & $63 \%(134)$ & $57 \%(67)$ \\
\hline $26-50 \%$ & $26 \%(56)$ & $31 \%(37)$ \\
\hline $51-75 \%$ & $9 \%(20)$ & $11 \%(13)$ \\
\hline $76-100 \%$ & $1 \%(2)$ & $1 \%(1)$ \\
\hline
\end{tabular}

$\%$ Students Eligible for Free and Reduced-

Price Lunch a, c

\begin{tabular}{|c|c|c|}
\hline $0-25 \%$ & $10 \%(22)$ & $2 \%(3)$ \\
\hline $26-50 \%$ & $25 \%(53)$ & $33 \%(41)$ \\
\hline $51-75 \%$ & $49 \%(103)$ & $56 \%(70)$ \\
\hline $76-100 \%$ & $8 \%(16)$ & $8 \%(10)$ \\
\hline $\begin{array}{l}\text { District Participated in the Competitive Pro- } \\
\text { gram }^{d}\end{array}$ & $10 \%(22)$ & $17 \%(21)$ \\
\hline District Participated in the Opt-In Program ${ }^{d}$ & $58 \%(124)$ & $100 \%(124)$ \\
\hline
\end{tabular}

participate in the competitive grant program compared with $68 \%$ of districts participating in the optin program.

\section{Reach of the Opt-In Grant Program}

Twenty-two districts participated in the competitive program in the baseline year compared with 124 districts in the intervention opt-in program. Table 2 shows that $88 \%$ of children in Oregon public schools attended districts participating in the intervention, an increase of $118 \%$ compared with the competitive program. The opt-in program also reached $96 \%$ more nonwhite children compared with the competitive program (approximately $89 \%$ of nonwhite students in the Oregon public school system were reached compared with $46 \%$ under the competitive program). Furthermore, the number of children eligible for free and reduced-price lunch participating in the opt-in program increased by $123 \%$ compared with the competitive program, reaching $78 \%$ of eligible children.

\section{Change in Local Purchasing with the Opt-In Grant Program}

Procurement grant funds for 2015-2016 totaled US $\$ 1.8$ million; grant funds received by individual 
districts ranged from US $\$ 279$ to US $\$ 166,596$ with an average of US $\$ 14,605$. The amount of funding depended on the district's average daily participation in the NSLP, meaning that larger districts with higher participation in school meals received more funding. Table 3 shows the total food purchases of districts including purchases of all local foods and local produce during baseline and the intervention. During baseline, total average food expenditures for procurement grant districts were approximately

Table 2. Number of Participating Districts and Children in Oregon (Baseline 2014-2015 versus Intervention 2015-2016)

\begin{tabular}{|c|c|c|c|}
\hline \multirow[b]{2}{*}{ District Characteristics } & \multicolumn{2}{|c|}{ Program } & \multirow{2}{*}{$\begin{array}{c}\text { Percentage Change } \\
\text { from Competitive to } \\
\text { Opt-In }\end{array}$} \\
\hline & $\begin{array}{l}\text { Competitive } \\
(2014-2015)\end{array}$ & $\begin{array}{c}\text { Opt-In } \\
(2015-2016)\end{array}$ & \\
\hline Grantee Districts $(n)$ & $10 \%(22)$ & $59 \%(124)$ & $464 \%(102)$ \\
\hline Students $(n)^{\mathrm{a}}$ & $41 \%(232,771)$ & $88 \%(508,092)$ & $118 \%(275,321)$ \\
\hline Nonwhite Students $(n)^{b}$ & $46 \%(95,131)$ & $89 \%(186,766)$ & $96 \%(91,635)$ \\
\hline $\begin{array}{l}\text { Students Eligible for Free and Reduced-Price } \\
\text { Meals }(n)^{c}\end{array}$ & $39 \%(112,641)$ & $89 \%(250,800)$ & $123 \%(138,159)$ \\
\hline Average Daily Participation in the NSLP $(n)^{d}$ & $35 \%(104,063)$ & $78 \%(235,309)$ & $126 \%(131,246)$ \\
\hline
\end{tabular}

NSLP = National School Lunch Program.

a 2015-2016 data are from ODE (n.d.).

${ }^{b}$ Race/ethnicity data are from ODE (2019c).

${ }^{c}$ Free and reduced-price lunch data are from ODE (2019b).

d Average daily participation data are from USDA, Food and Nutrition Service (2019, October 4).

Table 3. Local Food Purchases for 2014-2015 and 2015-2016 for Opt-In Districts

\begin{tabular}{|c|c|c|c|c|c|}
\hline & $\begin{array}{l}\text { Mean Expenditures } \\
\text { SY 2014-2015 } \\
\text { (US\$) }\end{array}$ & $\begin{array}{c}\text { Percentage of Mean } \\
\text { Total Food Expendi- } \\
\text { tures SY 2014-2015 } \\
(\%)\end{array}$ & $\begin{array}{l}\text { Mean Expenditures } \\
\text { SY 2015-2016 } \\
\text { (US\$) }\end{array}$ & $\begin{array}{c}\text { Percentage of Mean } \\
\text { Total Food Expendi- } \\
\text { tures SY 2015-2016 } \\
(\%)\end{array}$ & $p$-value \\
\hline \multicolumn{6}{|l|}{ All Opt-In Districts $(N=121)$} \\
\hline Total Food Expenditures & 650,141 & & 655,269 & & .743 \\
\hline All Local Food Purchases & 115,178 & $17.72 \%$ & 121,381 & $18.52 \%$ & .264 \\
\hline $\begin{array}{l}\text { Local Fruit and Vegetable } \\
\text { Purchases }\end{array}$ & 12,867 & $1.98 \%$ & 15,281 & $2.33 \%$ & .154 \\
\hline \multicolumn{6}{|l|}{ High-Income Opt-In $(N=23)$} \\
\hline Total Food Expenditures & 982,985 & & 940,007 & & .277 \\
\hline All Local Food Purchases & 208,413 & $21.20 \%$ & 187,853 & $19.98 \%$ & .171 \\
\hline $\begin{array}{l}\text { Local Fruit and Vegetable } \\
\text { Purchases }\end{array}$ & 30,258 & $3.08 \%$ & 25,454 & $2.71 \%$ & .259 \\
\hline \multicolumn{6}{|l|}{ Low-Income Opt-In $(N=98)$} \\
\hline Total Food Expenditures & 572,025 & & 588,442 & & .334 \\
\hline All Local Food Purchases & 93,296 & $16.31 \%$ & 105,780 & $17.98 \%$ & .033 \\
\hline $\begin{array}{l}\text { Local Fruit and Vegetable } \\
\text { Purchases }\end{array}$ & 8,785 & $1.54 \%$ & 12,893 & $2.19 \%$ & .025 \\
\hline
\end{tabular}

Notes: Low-income district was defined as $40 \%$ of children in the district qualify for free and reduced-price meals. Districts were included in the analysis if they provided both baseline and progress report data. We used a paired two-sample $t$-test to determine whether the average purchases of local products (all local products and specifically local produce) were higher in 2015-2016 than in 2014-2015. 
US $\$ 650,000$, with high-income districts averaging US $\$ 983,000$ compared with US $\$ 572,000$ for lowincome districts. Overall, during the baseline year, opt-in districts spent $17.7 \%$ of their food expenditures on local foods at baseline or approximately US $\$ 115,000$ per district, with nearly $2 \%$ of budgets spent explicitly on local produce.

During the intervention year, opt-in districts spent $18.5 \%$ of their budgets on local food purchases, which was an increase from baseline. The increase was driven by low-income grantee districts increasing their average local purchases $(17.98 \%$ of total food expenditures), particularly local fruit and vegetable purchases $(2.19 \%$ of total food expenditures; $12.19 \%$ of all local expenditures) by a statistically significant amount as can be seen in Table 3. These $p$-values can be interpreted as evidence of a difference in all local food purchases and, specifically, local produce purchases between the baseline and intervention years among lowincome districts. No such difference was found among higher-income districts. However, it is important to note that the increase in total purchases is the amount of their grant funding. Technically, districts could use the grant funding in place of the funds they had previously used to purchase local products rather than make additional purchases, although this practice was discouraged. ${ }^{1}$ While average purchases of local products, including fruits and vegetables, decreased for high-income districts, Table 3 shows that this decrease was not statistically significant. Purchases of local products decreased probably because these districts received higher amounts of grant funding under the competitive program compared with the opt-in program.

In addition to purchasing local foods, some districts supplemented grant funds with school garden produce. Thirty-seven percent of opt-in districts incorporated school garden produce into cafeteria meals at one or more schools within their district, and $78 \%$ of these districts were low income. Furthermore, smaller districts (fewer than five schools in the district) incorporated school garden produce in their cafeteria meals more than larger districts.

\section{Conclusions and Discussion}

Limited studies have examined specific policies that encourage districts to engage in farm-to-school activities. Such evaluations are complex, given the interconnectedness of the NSLP, farm-to-school, and other state programming focused on nutrition and child health. Thus, it is difficult to disentangle the impacts resulting from any one particular policy.

Evaluating state policy and implementation changes such as those that took place in Oregon from 2014 to 2016 can help guide the development of more robust and effective state and local farmto-school policies in Oregon and elsewhere. This limited study examined the effects of Oregon's farm-to-school policy on low-income school districts related to the reach of the grant program and the purchase of local foods, specifically fruits and vegetables. Our findings, which are mainly descriptive, indicate that the policy, with its increased funding for school districts, increased the reach of the grant program for nonwhite students and lowincome districts through its opt-in process. Specifically, the number of nonwhite students attending a district participating in farm-to-school nearly doubled. Further, $81 \%$ of participating districts were low income, which is much higher than the percentage of districts characterized as low income $(65 \%)$ statewide. Additionally, under the opt-in program, $89 \%$ of children eligible for free and reduced-price meals attended schools in participating districts compared with $39 \%$ of eligible children under the competitive program. These facts demonstrate that the opt-in policy has been successful at reducing the barriers for lowincome districts and children to participate in farmto-school.

Furthermore, the policy increased the average total local food purchases for low-income districts, particularly fruits and vegetables. However, the findings also indicate that high-income districts, as a group, decreased their total purchases of local products with the opt-in grant program. As noted earlier, this may be because a higher proportion of the high-income school districts participated in the competitive grant program the year before and re-

\footnotetext{
${ }^{1}$ The 2017 legislation was revised to specify that grant funds should not be used to supplant existing purchases of Oregon foods.
} 
ceived a larger amount of grant funding that year, meaning that their funding actually decreased during the opt-in program for local food purchases.

Additionally, the preliminary research suggests that larger school districts face barriers incorporating school garden produce into school lunches. This could be occurring for two reasons, both of which we heard during interviews with school foodservice directors. First, given the number of students they serve, smaller districts can use the limited school garden produce across all of the schools in their district, while the volume of produce needed by larger districts is more sizeable with gardens unlikely to meet the demand for all schools. Therefore, the larger districts choose to use the garden produce for taste tests or educational purposes. Second, larger school districts may have contracts with produce distributors or foodservice management companies, making it more difficult to change cafeteria offerings.

Because of the opt-in nature of the legislation, a control group was not possible, which is a limitation to this study. A control group would have served as a stronger baseline to compare the districts and assess the effect of the grant funding while minimizing the effect of all other variables. These data would have been available if a policy analysis or evaluation had been supported during the pilot or competitive program. A second limitation is that generalizations from Oregon's farm-toschool legislation cannot be made because of unique program attributes (providing US $\$ 4.5$ million in state funds, $80 \%$ of the funding set aside for local procurement and available to all districts on an opt-in basis, while $20 \%$ of the funding allocated to education grants through a competitive process). Nevertheless, this evaluation does offer useful insights into policy design and implementation for other states that are considering farm-to-school policies. As described above, the opt-in approach to the grant program facilitated greater participation from low-income districts that may not have accessed the grant program otherwise. Research on other states using an opt-in approach for grant programs aimed at reaching low-income school districts (for farm-to-school or any other intervention) can provide insights into the efficacy of this approach for reaching low-income districts or other target audiences. Further, Oregon's policy approach of designating funds for procurement and/or education grants (versus generic farm-toschool grants to be used at the discretion of the district) enabled the prioritization of these activities in grantee districts. Research on the impact of similar policies or grant programs that target the use of funds to specific activities within a broader farmto-school approach can corroborate the efficacy of these policy design elements and findings from this study.

Legislation that progresses over time, like the iterations of Oregon's farm-to-school procurement policy (and associated education grant program), is a strategy for moving farm-to-school activities from a pilot to an institutionalized format within the school system. The initial grant funding (competitive or opt-in) can jumpstart the adoption of farm-to-school activities especially in low-income districts, by providing the opportunity for school administration to witness the benefits of farm-toschool. As with any grants or external funding provided to schools, the hope is that the demonstrated benefit in itself is a compelling argument for self-sustaining the activities without grant funding (competitive or opt-in) in the future. Future studies conducting a multiyear follow-up on the grantee districts could provide valuable insights into the sustainability of activities seeded by grant funding, as well as the ability of districts to leverage other funds to supplement funds enabled through state policy. These findings, in turn, could be incorporated into future policy and grant program design. For example, if the longitudinal data demonstrate that a majority of school districts needed at least three years of grant funding to signal elements of self-sustainability, then the grant program could be structured to provide funds to a district for three consecutive years with requirements for demonstrating sustainability and leveraging other funds.

Additional research can help develop a more thorough understanding of the long-term impacts of Oregon's farm-to-school policy on children's health outcomes and on other intended outcomes on farmers and the local economy. Future research could assess the impacts of the grant program on children's eating behaviors, particularly in low- 
income districts; farmer incomes, market expansion, and viability; and economic and employment multipliers for the state. Future research could also consider comparing policy models and impacts across states implementing farm-to-school policies to provide insight into impactful approaches and best practices to guide the field.

\section{Acknowledgments}

The following colleagues provided assistance during the research of this study: Rick Sherman, Oregon Department of Education; Amy Gilroy, Oregon Department of Agriculture; Megan Kemple, Oregon Farm to School and School Garden Network; and Katy Pelissier, Ecotrust.

\section{References}

Bontrager Yoder, A. B., Liebhart, J. L., McCarty, D. J., Meinen, A., Schoeller, D., Vargas, C., \& LaRowe, T. (2014). Farm to elementary school programming increases access to fruits and vegetables and increases their consumption among those with low intake. Journal of Nutrition Education and Behavior, 46(5), 341-349. https://doi.org/10.1016/j.jneb.2014.04.297

Cullen, K. W., \& Chen, T. A. (2017). The contribution of the USDA school breakfast and lunch program meals to student daily dietary intake. Preventive Medicone Reports, 5, 82-85. https://doi.org/10.1016/j.pmedr.2016.11.016

Hayes, D., Contento, I. R., \& Weekly, C. (2018). Position of the Academy of Nutrition and Dietetics, Society for Nutrition Education and Behavior, and School Nutrition Association: Comprehensive nutrition programs and services in schools. Journal of Nutrition Education and Behavior, 50(5), 433-439. https://doi.org/10.1016/i.jneb.2018.03.001

House Bill 2649 (HB 2649-B). (2013). 77th Oregon Legislative Assembly-2013 Regular Session. Retrieved from https://olis.leg.state.or.us/liz/2013R1/Downloads/MeasureDocument/HB2649/Enrolled

Joshi, A., Azuma, A. M., \& Feenstra, G. (2008). Do farm-to-school programs make a difference? Findings and future research needs. Journal of Hunger \& Environmental Nutrition, 3(2-3), 229-246. https://doi.org/10.1080/19320240802244025

Koch, P., Wolf, R., Graziose, M., Gray, H. L., Trent, R., \& Uno, C. (2017). FoodCorps: Creating healthy school environments. New York, NY: Teachers College, Columbia University. Retrieved from https://foodcorps.org/cms/assets/uploads/2016/06/FoodCorps-Creating-Healthy-School-EnvironmentsTeachers-College.pdf

Kropp, J. D., Abarca-Orozco, S. J., Israel, G. D., Diehl, D. C., Galindo-Gonzalez, S., Headrick, L. B., \& Shelnutt, K. P. (2018). A plate waste evaluation of the farm to school program. Journal of Nutrition Education and Behavior, 50(4), 332339. https://doi.org/10.1016/j.jneb.2017.10.005

McCarthy, A. C., Steiner, A. S., \& Houser, R. F. (2017). Do state farm-to-school-related laws increase participation in farm-to-school programs? Journal of Hunger \& Environmental Nutrition, 12(4), 466-480. https://doi.org/10.1080/19320248.2017.1284026

Morris, J. L., \& Zidenberg-Cherr, S. (2002). Garden-enhanced nutrition curriculum improves fourth-grade school children's knowledge of nutrition and preferences for some vegetables. Journal of the Academy of Nutrition and Dietics, 102(1), 91-93. https://doi.org/10.1016/s0002-8223(02)90027-1

Murphy, J. M. (2003). Education for sustainability: Findings from the evaluation study of the edible schoolyard. Berkeley, CA: Center for Ecoliteracy.

National Cancer Institute. (2018). Usual dietary intakes: Food intakes, U.S. population, 2007-10. Retrieved from Epidemiology and Genomics Research Program website: https://epi.grants.cancer.gov/diet/usualintakes/

National Farm to School Network. (n.d.). About farm to school. What is farm to school, and how does it contribute to vibrant communities? Retrieved September 2018 from http://www.farmtoschool.org/about/what-is-farm-to-school

National Farm to School Network \& Center for Agriculture and Food Systems. (2019). State farm to school policy handbook: 2002-2018. Retrieved from http://www.farmtoschool.org/resources-main/statepolicyhandbook

Nicholson, L., Turner, L., Schneider, L., Chriqui, J., \& Chaloupka, F. (2014). State farm-to-school laws influence the availability of fruits and vegetables in school lunches at US public elementary schools. Journal of School Health, 84(5), 310-316. https://doi.org/10.1111/josh.12151 
Oregon Department of Education. (2017, September 26). BL PR comparison data updated 9-26-17.xlsx [Data file].

Oregon Department of Education. (n.d.). Reports \& data. Retrieved from https://www.oregon.gov/ode/reports-and-data/Pages/default.aspx

Oregon Department of Education. (2019a). Students eligible for free or reduced lunch. Retrieved in February 2019; no longer accessible online.

Oregon Department of Education. (2019b). Student ethnicity. Retrieved from in February 2019, no longer accessible online.

Ralston, K., Beaulieu, E., Hyman, J., Benson, M., \& Smith, M. (2017). Daily access to local foods for school meals: Key drivers (Economic Information Bulletin No. 168). Washington, DC: USDA Economic Research Service. Retrieved from https://www.ers.usda.gov/webdocs/publications/82945/eib-168.pdf?v=42816

Ratcliffe, M. M., Merrigan, K. A., Rogers, B. L., \& Goldberg, J. P. (2009). The effects of school garden experiences on middle school-aged students' knowledge, attitudes, and behaviors associated with vegetable consumption. Health Promotion Practice, 12(1), 36-43. https://doi.org/10.1177/1524839909349182

Savoie-Roskos, M. R., Wengreen, H., \& Durward, C. (2017). Increasing fruit and vegetable intake among children and youth through gardening-based interventions: A systematic review. Journal of the Academy of Nutrition and Dietetics, 117(2), 240-250. https://doi.org/10.1016/j.jand.2016.10.014

Schmidt, M. C., Kolodinsky, J., \& Symans, C. (2006). The Burlington School food project, final evaluation report. Burlington, VT: Center for Rural Studies, Vermont University. Retrieved from http://www.farmtoschool.org/resources-main/the-burlington-school-food-project-final-evaluation-report

Schneider, L., Chriqui, J., Nicholson, L., Turner, L., Gourdet, C., \& Chaloupka, F. (2012). Are farm-to-school programs more common in states with farm-to-school-related laws? Journal of School Health, 82(5), 210-216. https://doi.org/10.1111/j.1746-1561.2012.00689.x

Upstream Public Health \& Oregon Farm to School and School Garden Network. (2018). Political history of Oregon's farm to school and school garden program. Retrieved from http://www.farmtoschool.org/resources-main/a-working-history-of-farm-to-school-legislation-in-oregon

U.S. Department of Agriculture, Food and Nutrition Service. (2019, October 4). National School Lunch Program: Total participation. Retrieved from https://fns-prod.azureedge.net/sites/default/files/resource-files/01slfypart-10.pdf (no longer available online).

U.S. Department of Education. (2018, October 24). Improving basic programs operated by local educational agencies (Title I, Part A). Retrieved from https://www2.ed.gov/programs/titleiparta/index.html 